\title{
Memaksimalkan Metode Pembelajaran Team Assisted Individualy untuk Meningkatkan Hasil Belajar Pendidikan Kewarganegaraan Materi Pentingnya Keutuhan Negara Kesatuan Republik Indonesia (NKRI) pada Siswa Kelas V SDN Kraton 2 Maospati
}

\author{
Sutatik \\ SD Negeri Kraton 2 Maospati Kabupaten Magetan
}

\begin{abstract}
Abstrak
Penelitian ini adalah penelitian deskriptif untuk memperoleh informasi tentang hasil belajar, aktivitas Siswa, dan respon Siswa setelah mengikuti pembelajaran kooperatif tipeTeam Assisted Individualy.Penelitian ini merupakan jenis penelitian tindakan kelas (Classroom Action Research). Penelitian ini bertujuan untuk meningkatkan hasil belajar Kelas V SDN Kraton 2 Kabupaten Magetan Semester 1 pada pelajaran Pendidikan Kewarganegaraan materi Pentingnya Keutuhan Negara Kesatuan Republik Indonesia (NKRI) dengan menggunakan metode pembelajaran Team Assisted Individualy. Metode pengumpulan data yang digunakan adalah observasi, tes tulis, dan dokumentasi. Desain penelitian dimulai dari perencanaan, tindakan, pengamatan, dan refleksi. Indikator keberhasilan dari penelitian ini adalah lebih dari 75\% Siswa yang seharusnya tuntas KKM. Berdasarkan data penelitian terlihat bahwa pada prasiklus terdapat 52,9\% (18) Siswa tuntas KKM. Kemudian, pada siklus I terdapat 70,6\% (24) Siswa tuntas KKM. Kemudian, pada siklus II terdapat 82,4\% (28) Siswa tuntas KKM. Keberhasilan penelitian sesuai dengan indikator keberhasilan didapat saat siklus II, yaitu $82,4 \%$ Siswa tuntas KKM atau lebih dari $75 \%$ Siswa tuntas KKM.
\end{abstract}

Kata kunci: Pelajaran Pendidikan Kewarganegaraan, Kelas V, Hasil Belajar, Team Assisted Individualy.

\section{PENDAHULUAN}

Salah satu indikator suatu pendidikan dikatakan berkualitas jika outputatau perolehan nilai hasil belajar siswa sudah memenuhi kriteria yang sudah ditetapkan. Dalam pencapaian suatu pendidikan yang berkualitas maka diperlukannya beberapa penunjang dari indikator tersebut yaitu tersedianya sarana dan prasarana pendukung serta kecakapan guru dalam pengelolaankelas dan penguasaan materi yang cukup memadai. Dari beberapa indkator tersebut saling berkaitan antara satu dengan yang lain agar proses pembelajaran di sekolah atau lembaga pendidikan dapat berjalan sesuai dengan yang sudah ditentukan.

Berbagai faktor masukan yang melibatkan terjadinya proses pembelajaran di sekolah, yaitu masukan mentah (raw input) berupa siswa dengan segala karakteristiknya dan masukan instrumental (instrumental input) berupa kurikulum, guru, sarana dan prasarana termasuk media pembelajaran, dan proses belajar mengajar sebagai muara dari seluruh kegiatan pendidikan. Semua faktor tersebut sangatlah berpengaruh terhadap hasil belajar siswa, terutama guru dikarenakan guru yang 
merupakan salah satu sumber pengetahuan yang menyampaikan materi di dalm kelas.

Dalam proses belajar mengajar sedikitnya terdapat komponen: (1) tujuan yang akan dicapai, (2) bahan yang menjadi isi interaksi, (3) siswa yang aktif mengalami, (4) guru yang melaksanakan, (5) metode yang tepat, (6) situasi yang kondusif, (7) evaluasi atau penilaian terhadap hasil interaksi belajar.Selama peradaban dan kehidupan manusia itu sendiri masih ada maka persoalan pendidikan selalu saja ada. Apalagi dalam abad teknologi informasi seperti ini yang sangat berbengaruh pada dunia pendidikan, program pendidikan harus mengikuti perkembangan zaman serta selalu dianalisis sehingga akan mengetahui hambatanhambatan yang menjadi kendala, guna dicarikan solusi pemecahannya menuju suatu peningkatan.

Perkembangan teknologi yang digunakan oleh masyarakat dalam sistem produksi barang-barang dan jasa dewasa ini begitu cepat, tetapi dunia pendidikan belum dapat mengikuti perkembangan teknologi sebagai media pembelajaran di sekolah, maupun sebagai kelancaran penyelenggaraan sekolah. Dalam kagitan ini perlu diteliti sebagai penyebab rendahnya mutu pendidikan, antara lain: (1) kurikulum, (2) tenaga kependidikan, (3) metode belajarmengajar, (4) sarana dan prasarana, (5) lama pendidikan, (7) sistem penilaian, dan (8) anggaran pendidikan.

Dari keseluruhan hal tersebut faktor utama sebagai penyebab rendahnya mutu dan hasil belajar disinyalir karena rendahnya kualitas praktik pembelajaran di sekolah atau dapat dikatakan bahwa kegiatan belajar mengajar di sekolah belum optimal. Undang-undang Republik Indonesia Nomor 2 tahun 1989 tentang sistem Pendidikan Nasional, pasal 3 disebutkan pendidikan nasional berfungsi mengembangkan kemampuan dan membentuk watak serta peradaban bangsa, bertujuan untuk berkembangnya potensi peserta didik agar menjadi manusia yang beriman dan bertaqwa kepada Tuhan Yang Maha Esa, berakhlaq mulia, sehat, berilmu, cakap, kreatif, mandiri dan menjadi warga negara yang demokratis serta bertanggungjawab.

Dalam PP Nomor 1990 tentang pendidikan dasar, Pasal 3 dikemukakan bahwa pendidikan dasar bertujuan untuk memberi bekal kemampuan dasar kepada siswa untuk mengembangkan kehidupannya sebagai pribadi, anggota masyarakat, warga negara, dan umat manusia serta mempersiapkan siswa untuk mengikuti pendidikan menengah. Pendidikan dasar meliputi pendidikan di sekolah dasar (SD) dan di sekolah menegah tingkat pertama (SMP).

Salah satu permasalahan yang dihadapi oleh bangsa Indonesia saat ini adalah rendahnya mutu pendidikan. Berbagai usaha telah dilakukan untuk meningkatkan mutu pendidikan nasional, diantaranya dalam bidang pengelolaan sekolah, peningkatan sumber daya pendidikan, pengembangan/penulisan bahan ajar, serta pengembangan paradigma dengan metodologi pembelajaran.

Metode diskusi dan bercerita merupakan sebuah pendekatan pembelajaran yang berpijak pada keinginan untuk menghidupkan kelas dan menekankan pentingnya lingkungan alamiah diciptakan dalam proses belajar mengajar agar kelas lebih hidup dan lebih bermakna karena siswa mengalami sendiri apa yang dipelajari. Kelas yang hidup adalah kelas yang memberdayakan siswa dengan segala aktivitas belajarnya untuk mencapai kompetensi yang diinginkan sehingga 
diperoleh minat dan hasil belajar siswa yang optimal.

Rendahnya hasil belajar siswa di SDN Kraton 2 Maospati Kabupaten Magetandikelas V yang berjumlahkan 34 siswa dikarenakan beberapa hal yaitu ketidakaktifan siswa dalam proses pembelajaran tampak pada siswa kurang bersemangat saat mendengar keterangan guru, siswa tidak ada yang memberikan respon saat diberi pertanyaan oleh guru, siswa tidak mencatat bagian-bagian penting dari keterangan guru, siswa tidak mau bertanya akan konsep yang kurang dimengerti atau memang tidak tahu apa yang akan ditanyakan. Hal tersebutkan dibuktikan ketika penelitimelihat nilai ulangan harian dari siswa/siswi tersebut, masih banyak yangmemiliki nilai di bawah kriteria ketuntasan minimal (KKM) yang sudah ditentukan oleh sekolah yaitu di bawah 75 .

Hasil belajar yang diperoleh ketika observasi ulangan harian hanya 52,9\% dari 34 siswa yang tuntas KKM. Terkait dengan hal tersebut, peneliti mencoba melakukan penelitian tindakan kelas untuk meningkatkan hasil belajar siswa dengan menggunakan metode pembelajaran Team Assisted Individualization. Model pembelajaran kooperatif tipe Team Assisted Individualy termasuk dalam pembelajaran kooperatif. Dalam model pembelajaran Team Assisted Individualy, siswa ditempatkan dalam kelompok-kelompok kecil (4 sampai 5 siswa) yang heterogen dan selanjutnya diikuti dengan pemberian bantuan secara individu bagi siswa yang memerlukannya. Sebelum dibentuk kelompok, siswa diajarkan bagaimana bekerja sama dalam suatu kelompok.

Siswa diajari menjadi pendengar yang baik, dapat memberikan penjelasan kepada teman sekelompok, berdiskusi, mendorong teman lain untuk bekerja sama, menghargai pendapat teman lain, dan sebagainya.Masing-masing anggota dalam kelompok memiliki tugas yang setara. Karena pada pembelajaran kooperatif keberhasilan kelompok sangat diperhatikan, maka siswa yang pandai ikut bertanggung jawab membantu temannya yang lemah dalam kelompoknya. Dengan demikian, siswa yang pandai dapat mengembangkan kemampuan dan ketrampilannya, sedangkan siswa yang lemah akan terbantu dalam memahami permasalahan yang diselesaikan dalam kelompok tersebut.

\section{Strategi Pembelajaran Team Assisted Individualization}

TAI (Team Assisted

Individualization) adalah salah satu jenis pembelajaran kooperatif (cooperative learning). Frase Team Assisted Individualization dapat diterjemahkan sebagai "Bantuan Individual Dalam Kelompok (BIDaK)". Model pembelajaran kooperatif TAI ini sering pula dimaknai sebagai Team Accelerated Instruction.

Masing-masing anggota dalam kelompok memiliki tugas yang setara. Karena pada pembelajaran kooperatif keberhasilan kelompok sangat diperhatikan, maka siswa yang pandai ikut bertanggung jawab membantu temannya yang lemah dalam kelompoknya. Dengan demikian, siswa yang pandai dapat mengembangkan kemampuan dan ketrampilannya, sedangkan siswa yang lemah akan terbantu dalam memahami permasalahan yang diselesaikan dalam kelompok tersebut (Suyitno, 2002).

Model pembelajaran kooperatif tipe TAI (Team Assisted Individualization) merupakan pembelajaran kooperatif yang pada pelaksanaannya peserta didik dibagi ke dalam kelompok-kelompok kecil yang heterogen. Salah satu poin penting yang harus diperhatikan untuk membentuk 
kelompok yang heterogen di sini adalah kemampuan akademik peserta didik. Masing-masing kelompok dapat beranggotakan 4-5 orang peserta didik. Sesama anggota kelompok berbagi tanggung jawab.

Model pembelajaran kooperatif tipe TAI (Team Assisted Individualization atau Team Accelerated Instruction) merupakan strategi pembelajaran yang berpusat pada peserta didik (student centered). Pada model pembelajaran kooperatif ini, peserta didik biasanya belajar menggunakan LKS (lembar kerja peserta didik) secara berkelompok. Mereka kemudian berdiskusi untuk menemukan atau memahami konsepkonsep. Setiap anggota kelompok dapat mengerjakan satu persoalan (soal) sebagai bentuk tanggungjawab bersama. Penerapan model pembelajaran kooperatif Team Assisted Individualization lebih menekankan pada penghargaan kelompok, pertanggungjawaban individu dan memperoleh kesempatan yang sama untuk berbagi hasil bagi setiap anggota kelompok.

Robert Slavin mengembangkan model pembelajaran kooperatif tipe Team Assisted Individualization ini di Johns Hopkins University bersama Nancy Madden dengan beberapa alasan, yaitu: (1) Model ini mengkombinasikan keunggulan kooperatif dan program pengajaran individual; (2) Model ini memberikan tekanan pada efek sosial dari belajar kooperatif; (3) TAI disusun untuk memecahkan masalah dalam program pengajaran, misalnya dalam hal kesulitan belajar peserta didik secara individual.

Model pembelajaran kooperatif tipe Team Assisted Individualization ini dikembangkan oleh Slavin untuk mata pelajaran matematika, khususnya untuk materi keterampilan-keterampilan berhitung (computation skills).
Pembelajaran kooperatif tipe Team Assisted Individualization ini dikembangkan oleh Slavin. Tipe ini mengkombinasikan keunggulan pembelajaran kooperatif dan pembelajaran idnidvidual. Tipe ini dirancang untuk mengatasi kesulitan belajar peserta didik secara individual. Oleh karena itu, kegiatan pembelajarannya lebih banyak digunakan untuk pemecahan masalah, ciri khas pada tipe Team Assisted Individualization ini adalah setiap peserta didik secara individual belajar materi pembelajaran yang sudah dipersiapkan oleh pendidik. Hasil belajar individual dibawa ke kelompok-kelompok untuk didiskusikan dan saling dibahas oleh anggota kelompok, dan semua anggota kelompok bertanggung jawab atas keseluruhan jawaban sebagai tanggung jawab bersama.

Langkah-langkah pembelajaran kooperatif tipe Team Assisted Individualization adalah sebagai berikut: a) pendidik memberikan tugas kepada peserta didik untuk mempelajari materi pembelajaran secara individual yang sudah dipersiapkan oleh pendidik; b) pendidik memberikan kuis secara individual kepada peserta didik untuk mendapatkan skor dasar atau skor awal; c) pendidik membentuk beberapa kelompok. Setiap kelompok terdiri dari 4-5 peserta didik dengan tingkat kemampuan yang berbeda-beda (tinggi, sedang, dan rendah). Jika mungkin, anggota kelompok terdiri dari ras, budaya, suku yang berbeda tetapi tetap mengutamakan kesetaraan jender; d) hasil belajar peserta didik secara individual didiskusikan dalam kelompok. Dalam diskusi kelompok, setiap anggota kelompok saling memeriksa jawaban teman satu kelompok; e) pendidik memfasilitasi peserta didik dalam membuat rangkuman, mengarahkan, dan memberikan penegasan pada materi pembelajaran yang telah dipelajari; f) pendidik memberikan 
kuis kepada peserta didik secara individual; g) pendidik memberi penghargaan pada kelompok berdasarkan perolehan nilai peningkatan hasil belajar individual dari skor dasar ke skor kuis berikutnya (terkini).

Model pembelajaran tipe Team Assisted Individualization ini memiliki 8 tahapan dalam pelaksanaannya, yaitu : (1) Placement Test; (2) Teams; (3) Teaching Group; (4) Student Creative; (5) Team Study;(6) Fact Test;(7) Team Score dan Team Recognition; dan (8) Whole-Class Unit.

\section{METODE PENELITIAN}

Penelitian ini merupakan penelitian tindakan kelas atau Classroom Action Research. Penelitian Tindakan Kelas merupakan suatu bentuk penelitian yang berbentuk reflektif dengan melakukan tindakan tertentu untuk memperbaiki dan meningkatkan praktik pembelajaran di kelas secara lebih berkualitas sehingga siswa dapat memperoleh hasil belajar yang lebih baik (Asrori, 2008).Penelitian ini dilaksanakan di SDN Kraton 2 Maospati Kabupaten Magetan. Penelitian ini dilakukan pada bulan Julihingga Oktobersemester ganjil tahun pelajaran 2015/2016.Subjek dalam penelitian ini adalah Siswa kelas V SDN Kraton 2 Maospati Kabupaten Magetan yang berjumlah 29siswa.Objek dalam penelitian ini adalah mata pelajaran Pendidikan Kewarganegaraan yang khususnya materi Pentingnya Keutuhan Negara Kesatuan Republik Indonesia (NKRI).

Sumber data dari penelitian ini adalah semua aktivitas pembelajaran yang berhubungan dengan materi yang diteliti pada Siswa kelas V SDN Kraton 2 Maospati Kabupaten Magetan di semester I tahun pelajaran 2015/2016.Data yang diperoleh dalam penelitian ini adalah data kualitatif dan data kuantitatif yang terdiri atas (1) hasil belajar siswa dan (2) hasil observasi.

Penelitian ini dianggap berhasil apabila lebih dari $75 \%$ nilai siswa tuntas KKM. Nilai KKM pelajaran Pendidikan Kewarganegaraankelas V SDN Kraton 2 Maospati Kabupaten Magetan adalah 75.

\section{HASIL PENELITIAN DAN PEMBAHASAN}

Siklus I

Pelaksanaan siklus 1 dimulai dengan guru menyampaikan materi secara singkat dan jelas mengenai Fungsi Pancasila sebagai perekat persatuan bangsa.Guru di depan kelas menjelaskan materi dan siswa memperhatikan guru, sebagian siswa tidak paham mengenai materi yang dijelaskan dan ada siswa yang mengantuk.Guru membentuk kelompok kecil tiap kelompok beranggotakan 5 orang dan memberikan soal sebagai bahan diskusi tiap kelompoknya.Guru meminta siswa untuk membentuk kelompok yang beranggotakan 5 siswa dan duduk secara kelompok, siswa yang sudah duduk berkelompok guru memberikan beberapa soal yang ada di buku paket dan memintanya untuk mengerjakan secara diskusi.Setiap kelompok mengerjakan tugas dari guru.Masing-masing kelompok bekerjasama mendiskusikan soal yang sudah diberikan oleh guru, siswa mengerjakan soal ada yang saling debat ada pula beberapa siswa yang hanya berdiam diri.Ketua kelompok melaporkan keberhasilan kerja kelompoknya dan mempresentasikan hasil kerjanya.Meminta ketua kelompok untuk mempresentasikan hasil kerja diskusi di depan kelas, perwakilan ketua kelompok maju di depan kelas dan memaparkan hasil diskusi, sebagian siswa lain sibuk dengan kelomponya dan ada juga yang ramai bermain sendiri.Guru menetapkan kelompok 
terbaik sampai yang kurang berhasil berdasarkan hasil koreksi.Setelah diskusi selesai, guru menyampaikan hasil terbaik dari presentasi yang sudah dikerjakan serta dari hasil jawaban yang paling benar. Siswa seraya bersorak yang memperoleh nilai terbaik. Beberapa siswa acuh dengan apa yang sudah di sampaikan oleh guru.Guru dan peseta didik menyimpulkan bersama tentang materi yang sudah dipelajari dan evaluasi berupa soal post test. Di ujung pembelajaran guru menyimpulkan dan merfleksi proses pembelajaran dengan memberikan evaluasi berupa soal posttest yang dikerjakan secara individu.

Hasil refleksi yang dilakukan oleh observer disiklus I adalah pada saat membuat kelompok sebagian siswa tidak mau berkelompok dengan siswa yang berbeda jenis, sebaiknya guru memberikan motivasi kepada siswa mengenai pembagian kelompok. Berikan batasan waktu kepada siswa ketika berdiskusi agar proses pembelajaran dapat selesai sesuai dengan agendanya. Serta agar siswa memiliki tanggung jawab terhadap tugas yang diembannya. Siswa seakan malas mengerjakan tugas yang diberikan oleh guru, dan kurang antusias dalam mengikuti proses pembelajaran, guru sebaiknya memberikan suatu reward bagi siswa yang mempunyai nilai terbaik agar mereka bisa saling beradu secara sehat.

Siklus II

Pada siklus II guru menyampaikan materi pelajaran di depan kelas sambil memberikan tanya jawab langsung dengan siswa dan mengaitkan materi dengan kehidupan sehari-hari.Guru di depan kelas menjelaskan materi dan siswa memperhatikan guru di saat tertentu guru memberikan suatu pertanyaan kepada siswa agar siswa tidak mengantuk dan lebih siap dalam pembelajaran sesuai dengan saran
observer.Guru membagi siswa secara heterogen baik perempuan dan laki laki serta kemampuan berfikirnya membentuk kelompok kecil dengan tiap kelompok beranggotakan 4 orang.Guru membagi siswa menjadi beberapa kelompok yang tiap kelompoknya terdiri dari 4 siswa yang hetergen dan memiliki kemampuan yang berbeda. Siswa mencari anggota kelompoknya dan mulai bekerjasama. Meminta siswa untuk mengerjakan tugas secara individu yang ada di buku paket dengan waktu kurang lebih 10 menit. Sebelum berdiskusi guru meminta siswa untuk mengerjakan latihan soal yang ada buku paket, agar ketika diskusi siswa sudah memiliki bahan untuk diskusi, siswa mengerjakan secara individu dalam waktu 10 menit sesuai dengan saran observer.Guru mengintruksikan kepada siswa untuk mengerjakan secara kelompok untuk membandingkan hasil jawabannya.Setelah selesai meminta siswa untuk membandingkan hasil kerjanya dengan anggota kelompoknya untuk memperoleh jawaban yang paling tepat, siswa berdiskusi dengan anggota kelompoknya dan guru berkeliling antara kelompok satu dengan yang lain untuk embantu kesulitan siswa.Ketua kelompok melaporkan keberhasilan kerja kelompoknya dan mempresentasikan hasil kerjanya.Meminta ketua kelompok untuk mempresentasikan hasil kerja diskusi di depan kelas, perwakilan ketua kelompok maju di depan kelas dan memaparkan hasil diskusi, sebagian siswa lain sibuk dengan kelomponya dan ada juga yang ramai bermain sendiri.Guru menetapkan kelompok terbaik sampai yang kurang berhasil berdasarkan hasil koreksi.Setelah diskusi selesai, guru menyampaikan hasil terbaik dari presentasi yang sudah dikerjakan serta dari hasil jawaban yang paling benar. Siswa 
seraya bersorak yang memperoleh nilai terbaik. Guru memberikan soal postest untuk mengetahui pemahaman konsep siswa melalui hasil belajar siswa.Untuk mengetahui daya serap siswa, guru memberikan soal post test yang nantinya untuk mengetahui hasil belajar siswa, siswa mengerjakan soal secara individu.

\section{Hasil dan Analisis Penelitian}

Tabel 1. KKM siswa setiap siklus dan

\begin{tabular}{l|c|c|c}
\multicolumn{4}{c}{ persentasenya } \\
\hline & Prasiklus & $\begin{array}{c}\text { Siklus } \\
\text { I }\end{array}$ & $\begin{array}{c}\text { Siklus } \\
\text { II }\end{array}$ \\
\hline $\begin{array}{l}\text { Jumlah } \\
\text { siswa tuntas } \\
\text { KKM siswa }\end{array}$ & 18 & 24 & 28 \\
\hline $\begin{array}{l}\% \text { olos KKM } \\
\text { lolo }\end{array}$ & $52,9 \%$ & $70,6 \%$ & $82,4 \%$ \\
\hline $\begin{array}{l}\text { Rata-rata } \\
\text { nilai siswa }\end{array}$ & 72,9 & 80,6 & 86,3 \\
\hline
\end{tabular}

Tabel 1 memperlihatkan kenaikan jumlah siswa yang mencapai ketuntasan minimal disetiap siklus. Indikator keberhasilan dari penelitian ini adalah terdapat $75 \%$ siswa yang lolos KKM.

Berdasarkan data pada tabel 1 dapat dilihat bahwa pada prasiklus terdapat 52,9\%(18) siswa tuntas KKM. Kemudian, pada siklus I terdapat 70,6 \% (24) siswa tuntas KKM. Kemudian, pada siklus II terdapat 82,4 \% (28) siswa tuntas KKM. Keberhasilan penelitian sesuai dengan indikator keberhasilan didapat saat siklus II, yaitu $82,4 \%$ siswa tuntas KKM atau lebih dari $75 \%$ siswa tuntas KKM.

Nilai rata-rata unjuk kerja siswa di setiap siklus mengalami kenaikan. Pada prasiklus nilai rata-rata siswa hanya 72,9 atau masih di bawah KKM. Pada siklus I nilai rata-rata siswa adalah 80,6 . Pada siklus II nilai rata-rata siswa meningkat menjadi 86,3 atau telah berada di atas KKM.
Berdasarkan data pada tabel 1, dapat disimpulkan bahwa penggunaan metode Team Assisted Individualizationmampu meningkatkan hasil belajarSiswa kelas V SDN Kraton 2 Maospati Kabupaten Magetan pada pelajaran Pendidikan Kewarganegaraanmateri Pentingnya Keutuhan Negara Kesatuan Republik Indonesia (NKRI) semester I.

\section{PENUTUP}

Model pembelajaran kooperatif tipeTeam Assisted Individualytermasuk dalam pembelajaran kooperatif. Dalam model pembelajaran Team Assisted Individualy, siswa ditempatkan dalam kelompok-kelompok kecil (4 sampai 5 siswa) yang heterogen dan selanjutnya diikuti dengan pemberian bantuan secara individu bagi siswa yang memerlukannya. Sebelum dibentuk kelompok, siswa diajarkan bagaimana bekerja sama dalam suatu kelompok.

Siswa diajari menjadi pendengar yang baik, dapat memberikan penjelasan kepada teman sekelompok, berdiskusi, mendorong teman lain untuk bekerja sama, menghargai pendapat teman lain, dan sebagainya.Masing-masing anggota dalam kelompok memiliki tugas yang setara. Karena pada pembelajaran kooperatif keberhasilan kelompok sangat diperhatikan, maka siswa yang pandai ikut bertanggung jawab membantu temannya yang lemah dalam kelompoknya. Dengan demikian, siswa yang pandai dapat mengembangkan kemampuan dan ketrampilannya, sedangkan siswa yang lemah akan terbantu dalam memahami permasalahan yang diselesaikan dalam kelompok tersebut.

Indikator keberhasilan dari penelitian ini adalah terdapat $75 \%$ siswa yang lolos KKM. Berdasarkan data 
penelitian terlihat bahwa pada prasiklus terdapat 52,9\%(18) siswa tuntas KKM. Kemudian, pada siklus I terdapat 70,6\% (24) siswa tuntas KKM. Kemudian, pada siklus II terdapat 82,4 \% (28) siswa tuntas KKM. Keberhasilan penelitian sesuai dengan indikator keberhasilan didapat saat siklus II, yaitu 82,4 \%siswa tuntas KKM atau lebih dari $75 \%$ siswa tuntas KKM.

Dapat disimpulkan bahwa metode

Team Assisted Individualizationmampu meningkatkan hasil belajarSiswa kelas V SDN Kraton 2 Maospati Kabupaten Magetan pada pelajaran Pendidikan Kewarganegaraanmateri Pentingnya Keutuhan Negara Kesatuan Republik Indonesia (NKRI) di semester I.

Berdasarkan hasil penelitian berikut disampaikan beberapa saran dalam upaya meningkatkan hasil belajar siswa: 1) perlunya dilakukan penelitian lain dengan pendekatan yang sama di materi pelajaran Pendidikan Kewarganegaraan yang lain; 2) waktu pembahasan harus diperbanyak, karena hal ini menentukan pemahaman siswa tentang materi; dan 3) minta siswa membahawa sumber referensi lain, agar pengetahuan dan wawasan siswa bertambah luas.

\section{DAFTAR PUSTAKA}

Asrori, Muhammad. (2009). Penelitian Tindakan Kelas. Bandung: CV Wacana Prima.

Depdiknas. (2005). Pendidikan Kewarganegaraan, Strategi dan Metode Pembelajaran Pendidikan Kewarganegaraan. Jakarta : Depdiknas Ngalimun. (2012). Strategi dan Model Pembelajaran. Banjarmasin. Scripta Cendekia.

Suyitno, Amin. (2004). Dasar-dasar dan Proses Pembelajaran Matematika I. Semarang: FMIPA UNNES. 